\title{
Role of Cash Waqf Linked Sukuk in Economic Development and International Trade
}

\author{
Hendri Tanjung ${ }^{1^{*}}$, Agus Windiarto ${ }^{2}$ \\ ${ }^{1}$ Universitas Ibn Khaldun Bogor, West Java, Indonesia \\ ${ }^{2}$ Lembaga Pembiayaan Ekspor Indonesia, Indonesia \\ E-mail: 1'hendri.tanjung@uika-bogor.ac.id, ${ }^{2}$ awindiarto@indonesiaeximbank.go.id
}

*) Corresponding author

\begin{abstract}
JEL Classification:
Abstract

F13

F63

The aim of this paper is to examine the role of Cash Waqf Linked

P33 Sukuk (CWLS) in economic development and trade in Indonesia. This research is motivated by the fact that there is still limited

Received: December 15, 2020 financing to economic development in Indonesia as well as trade financing. The research based on a qualitative methodology using the data from scientific journals and paper in the field of Cash

Revised: January 19, 2021 Waqf, including CWLS. The results cash waqf in several countries Accepted: January 25, 2021 has been used for beneficiaries. Especially for CWLS, it consists of 2 types, namely wakaf sukuk and retail waqf sukuk. For waqf sukuk, the proceeds of the waqf have been channelled to finance the construction of the retina center and glaucoma center at the hospital. Meanwhile, retail waqf sukuk are used by each nazir to finance the program. This research shows that CWLS is proven to play a role in economic development, particularly infrastructure. The infrastructure that has been built is in the health sector. CWLS can also be an alternative source of funds with low-cost of fund which in turn enables the Eximbank/ECA to extend trade financing to the cooperative with competitive price. However, there are some action need to be taken, i.e (i) conduct socialization regarding CWLS to improve public awareness and enlarge the wakif base and (ii) issue $D S N$ regulations regarding $C W L S$.
\end{abstract}

\section{Keywords:}

Cash Waqf Linked Sukuk, Trade Financing.

\section{How to Cite:}

Tanjung, H., \& Windiarto, A. (2021). Role of Cash Waqf Linked Sukuk in Economic Development and International Trade. Signifikan: Jurnal Ilmu Ekonomi, 10(2), 275-290. https://doi.org/10.15408/sjie.v10i2.20493. 


\section{Introduction}

International trade is one key issue in economic development. Seidman (2005) states economic development as "a process of creating and utilizing physical, human, financial, and social assets to generate improved and broadly shared economic well-being and quality of life for a community or region". Greenwood and Holt (2010) distinguish economic development from economic growth on the basis that economic development is a "broadly based and sustainable increase in the overall standard of living for individuals within a community", and measures of growth such as per capita income do not necessarily correlate with improvements in quality of life. Economic development was concerned with the expansion of people's entitlements and their corresponding capabilities, morbidity, nourishment, literacy, education, and other socio-economic indicators (Todaro \& Smith, 2011).

To support international trade (export/import), banks provide trade finance both cash loan and non-cash loan. The trade financing can be in the form of Letter of Credit (LC) or non-LC. In the case of LC, banks only rely on fulfilling documents in accordance with the agreement. The bank acts as an LC issuing bank for overseas buyers and on the other hand, the bank becomes an advising bank for domestic exporters. However, now the use of LC as a method of payment is decreasing on the contrary the use of non-LC such as money transfer is increasing. Financing for debtors in the context of international trade includes pre-shipment, production, and post-shipment facilities or starting from issuing LC for imports of raw materials, financing for working capital for production, up to LC for export, and/or negotiating export bills/discount bills. Exports meet their working capital needs. So that the underwriting process, which begins with a 5's C assessment of the debtor, is very important, including ensuring sustainable supply availability and importer credibility as well as the trade cycle pattern because this will affect the determination of the structure and financing agreement to be used.

In order to carry out financing activities, banks/Eximbank/ECA/financial institutions conduct fundraising both in the form of local currency and foreign currency through third party fundraising, loans and issuance of securities. Banks /Eximbank Bank/ECA/financial institutions seek to obtain funds from a variety of sources and obtain competitive interest rates to be channeled in the form of financing. This financing is needed by exporters and their suppliers i.e SMEs to increase their production capacity to meet market demand.

Based on International Trade Center (ITC) data, the Middle East and Turkey are among the non-traditional regions that have the largest total export potential for Indonesia. The total export potential value in this region (without the United Arab Emirates) reaches USD 6.9 billion, of which 58\% or around USD 4 billion is still untapped. Saudi Arabia and Turkey are the two main countries with a total potential of USD 2.5 billion and USD 1.9 billion, respectively. In addition, the ratio of untapped potential in the two countries is still very high, around 60\% for the market for Saudi Arabia and 53\% for the market for Turkey.

The main export commodities that can be increased to the Middle East and Turkey are Vegetable Oil (Palm Oil) and Motor Vehicles. Although currently the Palm Oil commodity has become Indonesia's main export commodity to the Middle East and 
Turkey, its potential value is still very large, reaching USD 1.4 billion with $54 \%$ of which has not been utilized. Indonesia's exports to the Middle East and Turkey are mostly in the form of the Palm Oil Fraction, so that apart from leveraging palm oil exports as a whole it also increases added value for Indonesian palm oil. Meanwhile, the potential for exports of motor vehicle products reached USD 797.8 million with a percentage of the untapped potential of around 29\%. Other diversified products for Indonesia in the Middle East and Turkey range from household appliances, textiles, to fruits and seeds. These products include: Textile Fibers from Tree Bark, Fans, Data Storage Devices, Lentils, Papaya Fruits, Microwaves, Vacuum Cleaners, Flat Roll Products, and Red Beans.

The current account deficit experienced by Indonesia is getting bigger which is a challenge for the government. All efforts to reduce the deficit were made to improve the position of foreign exchange reserves and strengthen the Indonesian Rupiah (IDR), which continued to experience pressure due to the current account deficit. For this reason, exports to the main export destination countries need to be accompanied by diversification of the export destination markets, including to OIC - The Organization of Islamic Cooperationmember countries as a commitment to encourage inter-OIC trade. One of the factors that will support export performance is access to finance for exporters. In line with the significant development of Indonesia's Islamic financial system in the last two decades, the choice of Islamic funding sources could be an alternative option.

Zakat, Infaq, Sadaqat (ZIS), and Waqf can be used for productive activities (in development programs), consumptive (food assistance), social facilities (hospitals and schools), business, and investment (property and shares). ZIS and Waqf have great potential to become modalities for development funding to improve social welfare while simultaneously realizing at least 5 SDGs goals, namely No poverty, No hunger, Good health, Quality education, and Reduced inequality. Likewise, the export sector is a productive sector and has positive social and economic impacts. The influence of waqf on the socio-economic conditions of Muslims shows significant evidence of the contribution of waqf to religious, economic and social activities such as mosque management and school development, for public and individual purposes. Cash waqf is an alternative method towards community development (Sanusi \& Shafiai, 2015). The mandate of managing waqf assets is generally held by Nadzir permanently until the assets survive or sustainably to generate economic benefits for the welfare of the community. In the traditional practice of waqf that originated in the Ottoman Empire, cash waqf was generally practiced as a form of investment in which the principal funds were continuously invested in potential investment opportunities. In its role as a waqf fund investment manager, mutual funds on behalf of the waqf institution can allocate a portion of the waqf funds to direct investment, channel funds, and finance Micro, Small and Medium Enterprises (MSME) businesses using a profit sharing system. The greater the investment return, the more funds that can be allocated for poverty alleviation programs (Masyita, 2001; Masyita, 2007).

The Islamic economic system aims to improve the welfare of society and realize maqasid as sharia, and uphold the value of justice, therefore an important basis for distributing zakat and waqf is the guidance of Allah in Surah of the Al Qur'an [59]. 
The foundation gave birth to a big concept of the role of zakat and waqf in economic development. Zakat and waqf are instruments of economic development. Empowerment and coordinative management between the government and the community make a positive contribution to the economic development of Muslims (Urif et al., 2019).

Waqf can be defined as holding Maal (assets) and preventing its consumption with the aim of repeatedly extracting the harvest for purposes that represent truth and lor philanthropy (Kahf, 1998). Waqf also known in English as 'Islamic belief' or 'pious foundation' is defined as an unrelated belief established under Islamic law by living men or women for the provision of designated social services in perpetuity (Kuran, 2001: 842). Waqf literally means holding, confining or prohibiting or prohibiting the movement, transportation or exchange of something (Raissouni, 2001). In line with the rise of sharia financing, of course, sharia-based sources of funds are also needed to support financing, including CWLS. Ismal et al. (2015) conducted a research in the case of Indonesia of which showed that Awqaf Linked Sukuk can support the economic development.

Sukuk (Arabic: صكوك, plural of صك Shak, "legal instrument, charity, check") is the Arabic term used for bonds based on sharia principles. In fatwa number 32/DSN-MUI/ IX/2002, the National Sharia Council of the Indonesian Ulama Council defines sukuk as long-term securities based on sharia principles issued by issuers to sharia bond holders which require the issuer to pay income to Islamic bond holders in the form of profit sharing margins or fee, as well as paying back the bond funds at maturity. Sukuk can also be defined as Sharia Securities in the form of certificates or proof of ownership of the same value and represents an integral or undivided part of the investment, consisting of: (a). ownership of certain tangible assets; (b). value of benefits and services for certain project assets or certain investment activities; or (c). ownership of certain project assets or certain investment activities.

Systemically, the waqf sector is part of the Islamic financial system that serves all segments of society. The commercial sector, which consists of Islamic banking, the capital market, and takaful, is here to entertain the middle and upper-income earners by providing financial products and services that are entirely on a commercial basis. Funds mobilized were channeled for various purposes related to production and consumption activities as well as infrastructure development. The government, in turn, can also mobilize funds through tax collection and also the issuance of government Sukuk to finance expenditures (general spending and infrastructure development). The Islamic social sector consisting of zakat and waqf exists to serve low-income people by providing cheap economic programs. These programs can include basic consumption, business incubation programs, health services, educational programs, etc.

From a macroeconomic perspective, the Islamic social sector can be seen as a suitable vehicle to complement the government's efforts to reduce poverty. Waqf assets are useful in many ways as follows: (a) Waqf infrastructure - assets can be used to support the community in supporting the economic activities of a community group that has not reached a critical period in production. Production costs can be brought to the level of economic competitiveness when offered to the market; (b) Low-cost funds - excess yields of waqf 
assets can be used in a flexible manner to support the economic development of low-income communities; and (c) Underlying/basic Islamic securities - waqf assets (especially land) can be the object of financing or issuing Islamic securities (particularly Sukuk) for social projects.

The benefits mentioned above are economically beneficial for expanding a country's production base; thereby strengthening national economic stability. The role of the Islamic social sector is providing investment portfolios with higher returns and more contributions to the economy. The presence of zakat and waqf funds opens opportunities to increase the supply of credit to the community without having to increase the potential risk because these facilities are available through specially designed contracts and the cost of funds is zero. The economic system will then have the opportunity to strengthen the financial cushion to secure economic production in normal times as well as financial difficulties (Ismal et al., 2015).

The existence of nadzir is very important in maintaining and managing waqf. According to Law Number 41 of 2004 concerning Waqf, Nadzir is divided into three, namely: individual nadzir, organizational nadzir and legal entity nadzir. Nadzir's efforts in developing waqf assets are productive waqf. In addition, what is no less important is the security of property assets donated with the status of charity from being contested by irresponsible parties. There are several things that must be done by the Examiner, such as: first, immediately providing land ownership certificates (if they have permanent assets, such as land). Second, perpetual assets advocate, which is still disputed. Third, strengthening productive waqf assets. Nadzir has a central role in the management of waqf in general. Therefore, the existence and quality of human resources must really be considered nadzir. Nadzir (both individuals, organizations and legal entities) must consist of people with dignity, honesty, good behavior, experience, mastering the administrative and financial knowledge needed to carry out their duties in accordance with the type of ownership and purpose. In general, waqf management can be directed and built optimally, if the nadzir is trustworthy and professional (Kasdi, 2014; Kasdi, 2018).

While the millions of waqf vary around the world, most of them fall into the five basic welfare categories namely food, housing, health, education and religion. Unfortunately, the vast amount of waqf assets and the institutions are not well managed. The best waqf buildings, with tremendous commercial potential, do not receive basic repairs and maintenance. The inevitable consequence is a lot of damage and damage. The source of the waqf archive is quite rich; However, the problem of waqf development has not been explored from the perspective of stakeholder theory. In order to revitalize waqf institutions, it is necessary to introduce stakeholder principles into the waqf institution. Professional business management techniques will undoubtedly create many positive opportunities for improving the quality of waqf institutions and delegating internal responsibilities. For the development of unused waqf properties, waqf institutions to fulfill their social goals, it is necessary to create a source of funding for the rebuilding of the aqwaf building by creating cash waqf funds and by issuing musharakah sukuk. The results of this initiative will be significant and more beneficiaries will benefit.

As one of the oldest forms of financial instrument, even before the existence of Islamic, waqf played a vital role throughout Islamic civilization. Waqf described as a 
powerful instrument to eliminate poverty, to restore social economy, and to create a distributive justice (Ahmad, 2015; Cizakca, 1998). The development of waqf land and properties is an important milestone for many Islamic institutions around the world given the fact that there are a large amount of undeveloped and ill-managed waqf land and properties in the Muslim world. Inevitably, the development of waqf land also involved problems and challenges such as lack of financial resources, undeveloped and unproductive waqf land, loopholes in the legal framework, unregistered waqf land, waqf on leasehold land, and land classified as heritage (Zulkhibri, 2017).

While, common waqf viewed as a traditional style of instrument on the form of endowed fixed asset, the new form of waqf, which is cash waqf is introduced to accommodate the flexibility utilization of waqf. Currently, there is consensus among the majority of Islamic jurist regarding the legitimacy of cash waqf. Many Muslim-majority countries have practiced many forms of waqf such as waqf shares scheme, deposit cash waqf scheme, compulsory cash waqf scheme, corporate waqf scheme, deposit product waqf scheme, and co-operative waqf scheme. Mohsin (2013) argued that cash waqf is acceptable as long as follow the same legal condition of immovable waqf. Even, cash waqf can be a new source of financing in the modern era.

Cash Waqf Investment model supports micro enterprises to improve their access to finance and enhance the skills. Intention and readiness of micro enterprises in accepting the model as a source of financial and human capital development services is impressive (Duasa \& Thaker, 2016). Return from cash waqf investment in unit trust also can be used to finance 11 items of federal government expenditures. The overall process can be managed by Yayasan Waqaf Malaysia through collaboration with an Islamic unit trust firm (Azrai et al., 2018).

Islamic Waqf Bank (IWB) can apply cash waqf structure, whereby the cash waqf fund must be converted into fixed assets such as land and buildings. The rental income from the fixed assets and investment then can be channeled to the waqf beneficiaries (Aziz, 2017). Beside combine with banking, Waqf-Ventura Capital Syariah (WVCS) is conceptualized based on the content analysis of cash waqf operations, profit and loss sharing modes and venture capital strategies. WVCS a integration between social finance (waqf) and commercial finance (Ventura capital) (Tanjung, 2018).

Based on capital market, the waqf shares scheme is relatively easy to raise funds from the public via traditional collections of money by cash or mobile payment systems which are widely used in Somalia. It is argued that the funds generated could be used to create employment opportunities, and as a result, many poor Somalis will be empowered financially, socially and educationally (Saiti et al., 2019). Lastly, cash waqf can combine with Islamic microfinance such as baitul maal wa tamwil. Sharía Cooperatives registered as cash waqf nazhir and in cooperation with Bandung City Fintech companies are owned by BMT ITQAN only where they are financed by itqanmobile and involve the Fintceh platform kitawakaf.com with the help of the House Financing Assembly empowerment program for BMT member SMEs with waqf funds and the waqf management models (Nurjamil, \& Nurhayati, 2021).

Meanwhile, other form of Islamic financial instrument, sukuk, had also been recognized in the past as instrument for international trade. In the Middle Ages, sukuk 
recognized as a recognition letter of obligation of a person who requested deferred his payment to certain party (Musari, 2019). Besides Waqf, Sukuk also became a vital role in a long story of Islamic civilization. In the modern era, sukuk resembles a conventional fixed-payment debt. But there is fundamental difference between sukuk and debt-based conventional payment on an ownership of the asset or an existing of the project.

The integration between cash waqf and sukuk enhance the benefit of the fund. Cash waqf linked sukuk (CWLS) can be alternative financing of different activities both of social and economic motives as long as its perpetuity preserved (look at Figure 1). The CWLS is deemed to have real sector development impact by having fixed tangible asset as an underlying (Ismal et al., 2015).

In order to promote the development of the domestic Islamic economy and financial market, it is necessary to have sharia-based investment instruments to optimize the use of public funds. The government or the Indonesian Waqf Board / financial institution with sovereign states can issue sharia-based securities in order to support fiscal sustainability and expand project financing. For this reason, in order to increase the potential of waqf through business and investment management, it is necessary to diversify and to have more option of the financial instruments, including CWLS.

Several countries have used cash waqf for several functions. Of course, Indonesia can also do benchmarking against these countries. For Indonesia, which has implemented CWLS, it is necessary to know the role of CWLS in development. What is more important is how likely it is that CWLS can finance export trade in Indonesia. From this background, the questions of this study are: (i) What are the role of Cash Waqf in different coutries? (ii) what is the role of cash waqf in Indonesia, especially CWLS? And (iii) what is the possible CWLS mechanism to finance trade in Indonesia? To answer those questions, this study was conducted.

Figure 1. Potential Origination of Awqaf Linked Sukuk

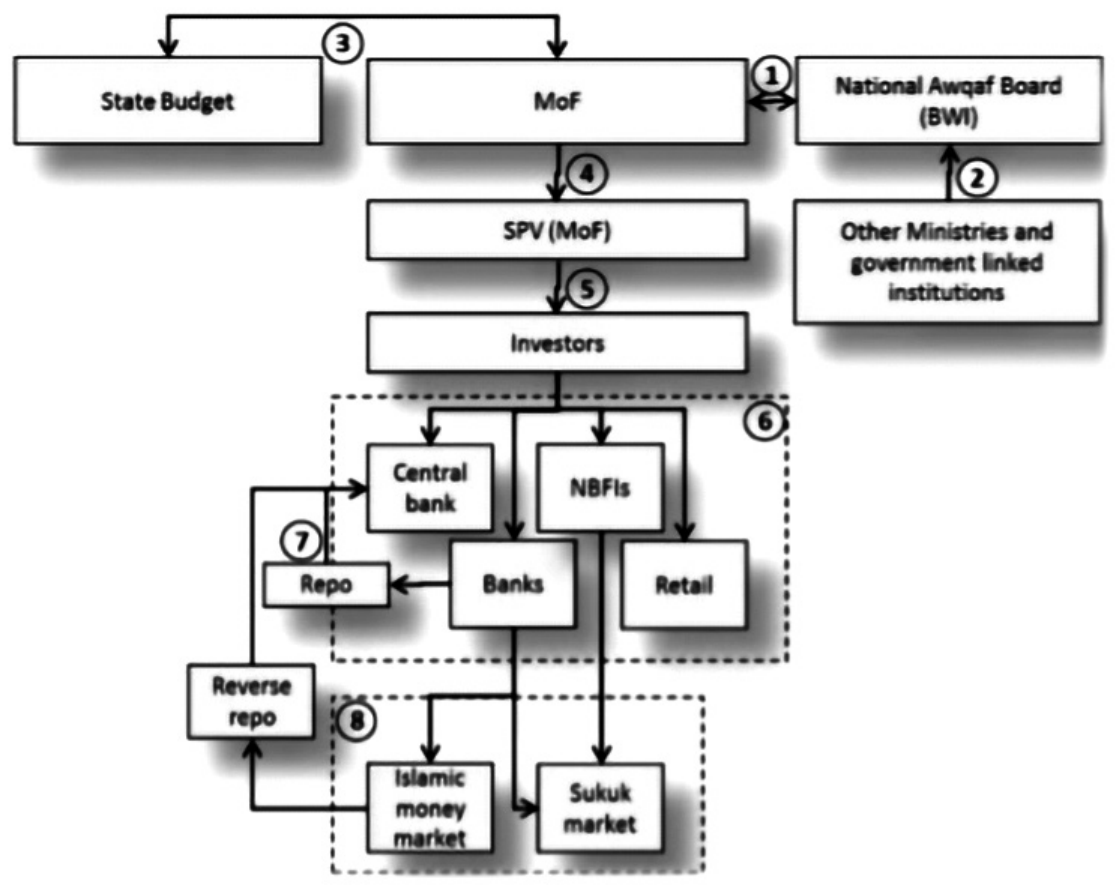


In Malaysia, cash waqf became alternative source of funding for micro enterprises. Thaker et al. (2016) proposed modification of Integrated Cash Waqf Micro Enterprise Investment (ICWME-I) model. Micro enterprises consider as a risky investment, therefore strict loan condition have been imposed such as collateral and proper support document. However, most of micro enterprise cannot fulfill the requirements. Thus, the idea ICWME-I is proposed to address financial constraint and enhance the development of economy.

In Indonesia, CWLS has become a study in the recent years as it has big potential in Indonesia. Mukhlisin \& Mustafida (2019) stated that CWLS very possible to launch in Indonesia refers to its benefit, opportunity, cost, and risk. Then, the government of Indonesia recently issued CWLS SW001 on 10 March 2020 by private placement by amount of Rp50,9 billion. The issuance of CLSW is a form of the government's commitment to support the development of social investment and the development of productive waqf in Indonesia.

\section{Methods}

The research method used is a qualitative method. The data referred to is from documents in the form of scientific journals and paper in the field of Cash Waqf, including CWLS. The analysis is content analysis of cash waqf operations and international trade financing.

\section{Result and Discussion}

\section{Role of Cash Waqf in the Different Countries}

Based on Mohsin (2013) research, we find that some role of cash waqf in the different countries. First, Waqf shares scheme. This scheme (Figure 2) is a public waqf which emerged in the last decades in Muslim and Muslim minority countries, such as Malaysia, Indonesia, Kuwait, and the UK. The main objective of this scheme is to generate money or to raise funds from the public to support the welfare of the society. The collection of this kind of funds is meant to finance lawful goods and services needed in the different societies. In early 2000, the Indonesia Waqf Board launched a cash waqf scheme known as Tabung Wakaf Indonesia/Indonesian Waqf Shares. The main objective of Indonesian Waqf Shares is to raise funds in order to finance many services that can benefit Muslim community at large. This scheme succeeded in financing poverty alleviation programs, providing free medical services to the poor and needy, arranging different educational programs and providing entrepreneur development programs (Timur, 2001).

Kuwait has succeeded in playing a great role, not only internally but also globally. Ten cash waqf schemes has been established namely (i) water wells scheme succeeded in constructing dams, digging surface wells and supplying the poor and needy with water coolers in India, Jordan, Somalia, Africa, Bangladesh, Nigeria and Somalia, (ii) educational scheme succeeded in financing educational and social charitable services such as sponsoring orphans, providing medical care, financing the teaching of Arabic and Islamic subjects and paying the salaries of teachers in Chad, Gambit, Philippine, Albania 
and Kosovo, (iii) mosques scheme succeeded in building and maintaining many mosques in many countries, such as Egypt, Kazakhstan, China and Togo, (iv) health care scheme succeeded in providing medical equipment and building hospitals in Egypt, building dental clinic in Palestine, building hospital in Philippine, and IICO hospital for cancer patients care in Kuwait, (v) training centers scheme succeeded in funding many centers, such as computer training centers in Africa, training institute in Indonesia, Nigeria, and Uganda, (vi) farms and productive projects succeeded in funding different farms and agriculture projects in Philippine, Bangladesh, India and Uganda, (vii) orphans scheme succeeded in sponsoring orphans, building and maintaining orphanages and providing orphans with proper education in Uganda, (viii) seasonal projects succeeded in financing the cost of preparing meals for breaking the fast/iftar during the month of Ramadhan, and distributing the meat during the month of sacrifices in Malawi, Nigeria, Cambodia, Kurdistan and Somalia, (ix) social projects scheme sponsored the cost of wedding in Sudan, besides sponsoring productive projects for needy families in Sudan and Palestine, and $(\mathrm{x})$ relief scheme succeeded in providing relief efforts in Kosovo and Palestine.

Figure 2. Waqf Shares Scheme

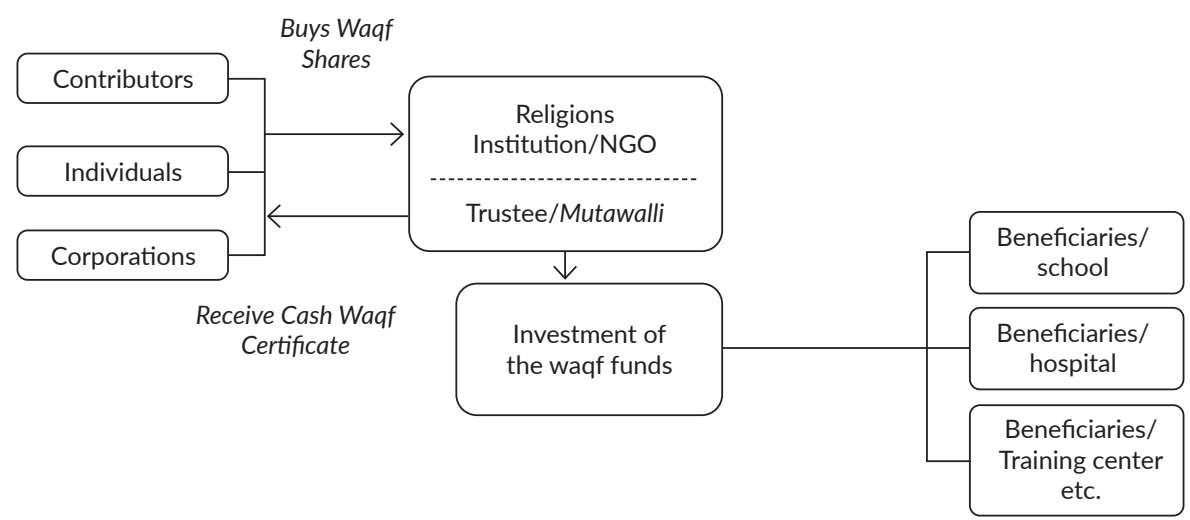

Second, Deposit cash waqf scheme. This scheme is also a public waqf which has been practised in Singapore, Bahrain and South Africa. The main purpose for this investment are to: finance the burials of poor Muslims, give aid to Muslim orphans, give aid to the Alsagoff School, and to finance other charity projects (Cizakca, 2000). Third, Compulsory cash waqf scheme. The compulsory cash waqf scheme (Figure 3) is also a public waqf which has been practised in Singapore. Fourth, Corporate waqf scheme This scheme (Figure 4) is also a public waqf which has been practised in Malaysia, Turkey, India, Pakistan and Bangladesh. The founder in this scheme is not only individual but private corporations and public corporation. Fifth, Deposit waqf product scheme. Similar to the deposit waqf scheme mentioned above, this deposit waqf product scheme is a public waqf which has been practised by two banks in Bangladesh, the Social Investment Bank Limited (SIBL) and the Islamic Bank Bangladesh Limited (IBBL) (Mannan, 1998). Sixth, Co-operative waqf scheme. This scheme (Figure 5) is a public waqf which has been practised in Uzbekistan (Sievers, 2002). This scheme has been established in 1992 to provide the basic needs for each district. 
Figure 3. Compulsory Cash Waqf Scheme

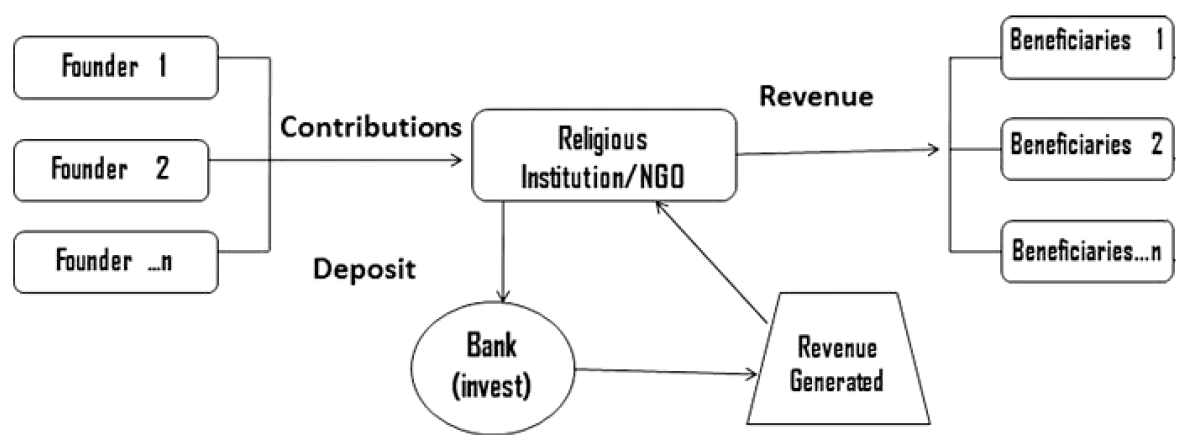

Figure 4. Corporate Waqf Scheme

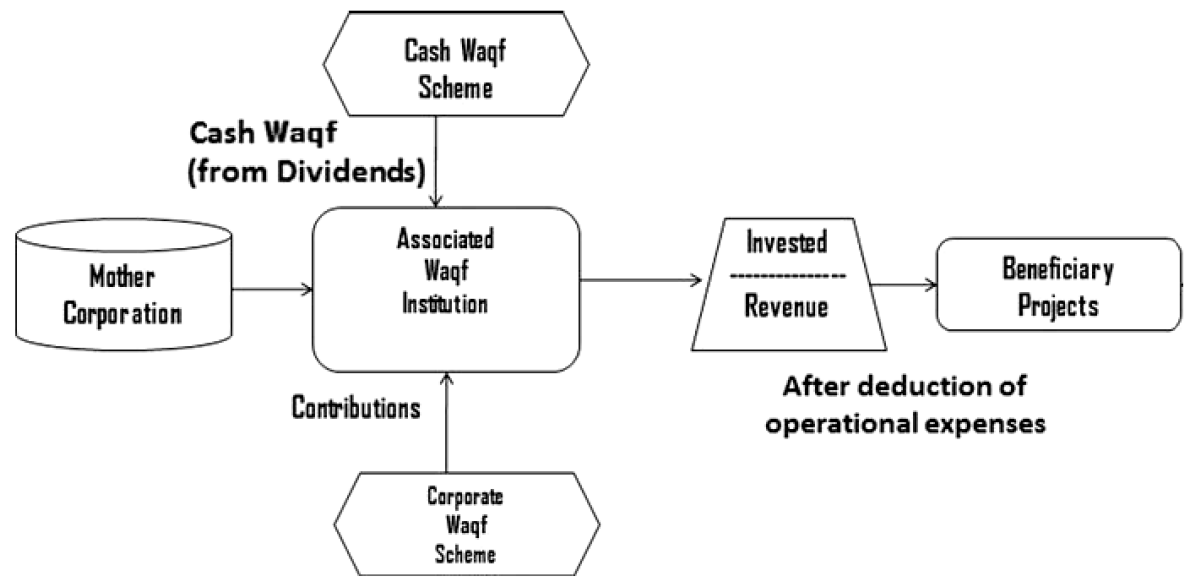

Figure 5. Co-operative Waqf Scheme

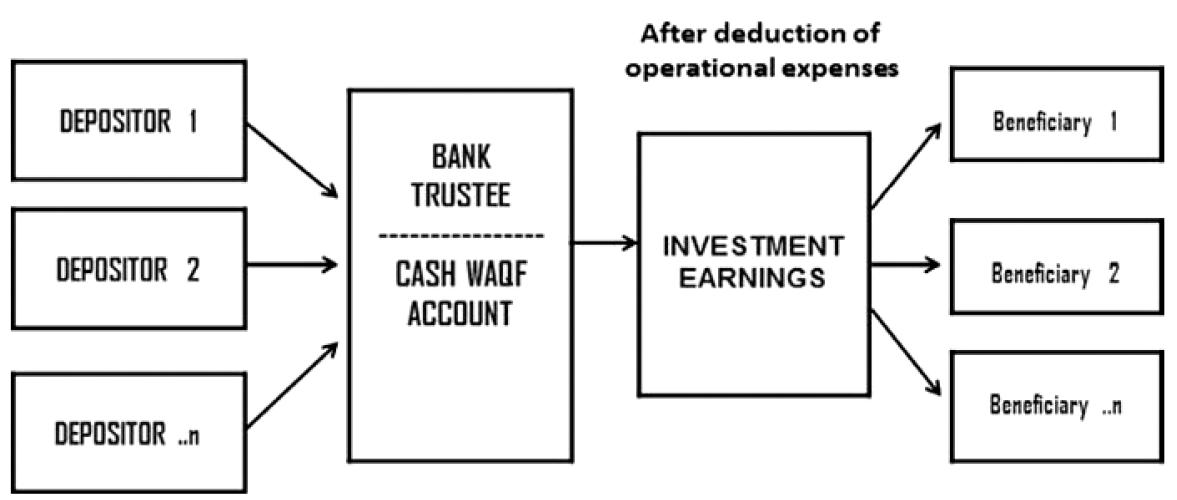

\section{Role of Cash Waqf in Economic Development in Indonesia}

The role of Cash Waqf in economic development in Indonesia is very important, especially Cash waqf linked sukuk (CWLS). There are 2 types of CWLS that have been launched, namely CWLS private placement and CWLS private retail. The target investors for this CWLS private placement are institutions. The Nazir is the Indonesian Waqf Board. The tenor is 5 years with a minimum order of 50 billion rupiahs. The maximum limit 
does not exist. The features of this CWLS product are nontradable. The product that has been issued is the first series of Sukuk Waqf, SW 001. The investment proceeds in the form of a discount used nazir for social infrastructure projects, while the coupons are for social programs / activities. For private retail CWLS, the target investors are individuals and institutions. The Nazirs were appointed based on the approval of the Indonesian Waqf Board. The tenor is 2 years with a minimum order of one million rupiahs. The maximum limit does not exist. The features of this CWLS product are nontradable. The product that has been issued is the first series of Retail Sukuk Waqf, SWR 001. The results of the investment are in the form of coupons, used as nazir for social programs/activities.

The stakeholders involved in the CWLS consist of at least the Indonesian Waqf Board, the Ministry of Finance, Bank Indonesia, Nazir Productive Waqf and Islamic Financial Institutions Receiving Cash Waqf Recipients. The Indonesian Waqf Board as the regulator, leader and Nazhir who manages the Cash Waqf Linked Sukuk. Ministry of Finance as a sukuk issuer and fund manager in the real sector. Bank Indonesia as an accelerator in encouraging the implementation of Cash Waqf Linked Sukuk and Custodian Bank. Nazhir Waqf Productive as a BWI partner who raises waqf funds. Sharia Bank (Bank Syariah Indonesia and Bank Muamalat) as LKS-PWU and BWI Operational Bank.

The issuance of Sukuk Waqf (Cash Waqf Linked Sukuk - CWLS) Series SW001 on March 10, 2020 is carried out by means of a private placement. The terms and conditions of the Sukuk Waqf series SW001 issued can be seen in Table 1. The results of SW001 have been used for the construction of a retina center and glaucoma center at the Ahmad Wardi Eye Hospital in Serang.

Table 1. Terms and Conditions Sukuk Wakaf Serial SW001

\begin{tabular}{clc}
\hline No. & \multicolumn{1}{c}{ Description } & sW001 \\
\hline 1. & Nominal Value & Rp 50.849.000.000,00 \\
2. & Form and Type of Sukuk & non-tradable \\
3. & Type of contract & Wakalah \\
4. & Yield & $6,15 \%$ \\
5. & Coupon & Fixed 5,00\% (per year) \\
6. & Date of issuance & $10^{\text {th }}$ March 2020 \\
7. & Due date & $10^{\text {th }}$ March 2025 \\
8. & First Coupon Payment & $10^{\text {th }}$ April 2020 \\
9. & Next Coupon payment date & The $10^{\text {th }}$ of every month \\
\hline
\end{tabular}

Source: djppr.kemenkeu.go.id

As for the Retail Sukuk Waqf Series SWR001, the conditions after the marketing closes on November 20, 2020 can be seen in Table 2. The results of this SWR001 will be used by the nazirs to make their program successful, such as scholarships for underprivileged students, subsidies for poor patients for medical treatment, etc. 
Some of the advantages of CWLS are: first, it is safe, because CWLS is guaranteed by the State. The funds will be returned $100 \%$ for temporary cash waqf, when the sukuk matures. Second, productive, because it provides returns that can be allocated to beneficiaries, in addition to providing cash waqf facilities. Third, blessings, because the results are used for public and social interests. The proceeds from the sukuk-wakaf investment are used to create new waqf assets and finance various social activities. Waqf candidates with a certain amount of waqf money can apply for social projects / activities to be implemented / financed. Competitive investment results. Fourth, long life, has an unbroken benefit because waqf property is eternal and will continue to be used forever.

Table 2. Terms and Conditions Sukuk Wakaf Ritel Serial SWR001

\begin{tabular}{cll}
\hline No. & \multicolumn{1}{c}{ Description } & \multicolumn{1}{c}{ SWR001 } \\
\hline 1. & Nominal Value & Rp 14.912.000.000,00 \\
2. & Form and Type of Sukuk & non-tradable \\
3. & Type of contract & Wakalah \\
4. & Coupon & Fixed 5,50\% (per year) \\
5. & Marketed Date & 9 \\
6. & Market closing date & 20 \\
7. & Underlying assets & State Property and the 2020 State Budget Project \\
\hline
\end{tabular}

Source: djppr.kemenkeu.go.id

CWLS has great potential as an instrument for financing development and social welfare. Waqf funds collected through CWLS can be used to finance development, and the proceeds are distributed to beneficiaries. Massive and structured socialization of cash waqf (in this case CWLS) needs to be done massively and structurally, so that in the end it will not only deepen the Islamic financial market, but also provide financial inclusion for the benefit of Muslims.

\section{CWLS Framework for Trade Financing in Indonesia}

Efforts to increase trade between Indonesia and OIC member countries must be supported by an understanding of the commodities needed in each export destination country and vice versa, the commodities needed by Indonesia from other OIC member countries. In this case, for Indonesia, it is necessary to start by building a halal value chain ecosystem that also has an intersection with SDGs in encouraging an increase in Indonesian exports. In the red bean and lentils comodities, the end-to-end process starts from (i) SME who are carrying out serial activities to fulfill the contract or purchase orders (P/O) starting from pre-harvest, post-harvest activities, delivery of goods to destination countries, (ii) the related ministry among others ministry of cooperatives and SMEs, ministry of trade, ministry of finance as well as ministry of foreign affair to provide market information, coaching program, and incentives, (iii) the financial institutions - bank/Eximbank/ECA support such activities through providing sharia-based financing funded from Cash Waqf 
Linked Sukuk in the form of (i) pre-shipment financing such LC to support the purchase of merchandise/raw-material from suppliers countries or money transfer service, working capital financing, (ii) post-shipment such as discounting export bills or cheque to receive funds for use as working capital before the bills or cheque due date.

Issuing CWLS as a source of funds for financing international trade with OIC member countries can be carried out by financial institutions that established under the law with the aim of encouraging national export performance. This is necessary considering that this financial institution has a sovereign status which provides certainty that it cannot be liquidated except by a law, will not experience dilution because it is $100 \%$ owned by the government, and focusing on activities related to international trade.

Figure 6 describes that there are 3 aspects in the scheme mentioned above, namely players, products, and markets. Cooperatives are economic activities that involve the participation of groups of people who produce red beans and lentils. In this case, it plays a role in fostering and improving the quality of red beans and lentils products to be exported. Red beans and lentils are plants that are widely distributed in Indonesia. Training and development of how to plant, fertilize, and harvest and process, and packaging apply the principles of sustainability, hygienists and/or encourages the role of women in economic activities. The market for red beans and lentils products is directed to OIC member countries. This is also an effort to increase intra-trade among member countries. The cargo used to send the two commodities is air transportation, which allows it to reach export destination countries in a shorter time so that the exported red beans and lentils are fresher.

Figure 6. CWLS framework for Trade Financing

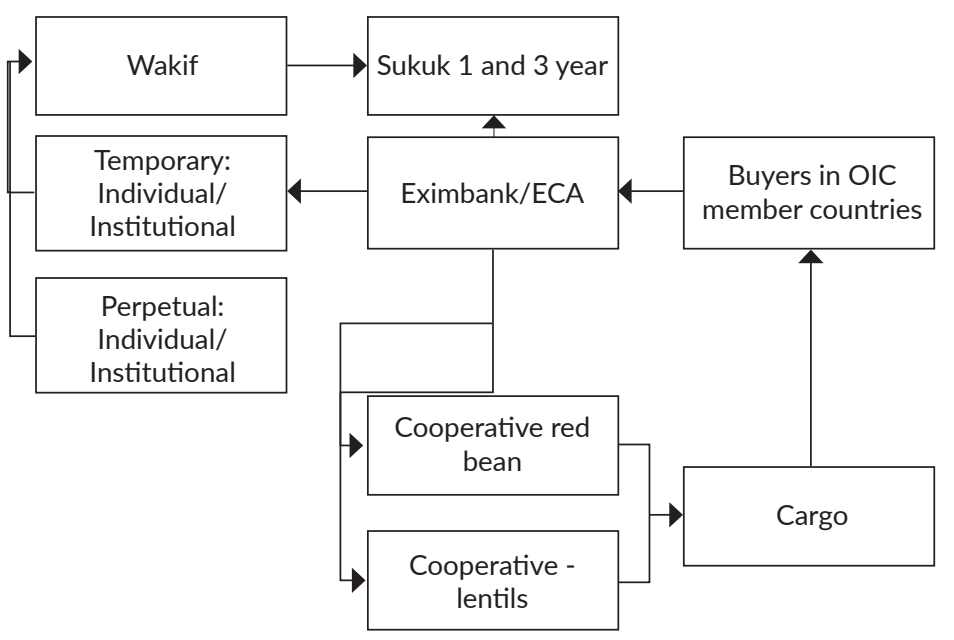

The CWLS issuance scheme is as follows:

1. Bank Issue Sukuk

2. Wakif buy Sukuk

3. Bank finance cooperative from sukuk

4. Cooperative use Cargo for transportation

5. Export to OIC member

6. Buyers pay to bank

7. Bank give back temporary waqf to waqif and return to Nazir.

Eximbank/ECA and wakif are enablers in this CWLS scheme. Eximbank / ECA, as a financial institution with sovereign status, issues Sukuk to finance the working capital needs of cooperatives scattered in several regions to produce red bean and lentils to be consumed by residents in OIC countries. The said working capital finance in the form of musyarakah or mudarabah will enable the cooperatives to produce and sell its product with 
competitive price as they are also enjoying very low margin compare to that of ordinary sharia finance. Wakif consist of individuals, institution and/or Islamic financial institutions both banks and non-banks that will place their funds. The placement of waqf funds in the Sukuk to be issued by Eximbank / ECA. The Sukuk that is specifically issued under the program of promoting export seeds to OIC member country can take the form of (i) placement of an endowment fund, namely principal and upon which is obtained; (ii) temporary placement of funds, upon maturity the principal is returned to the wakif.

Considering that the underlying transaction of this Sukuk is a working capital requirement of a red beans and lentils product cooperative, the Sukuk tenor can be issued in 2 tranches, namely tranches A with 1-year tenor and tranches B with 3 years' tenor with relatively low coupon compare to that of ordinary Sukuk. With the growing need for working capital to increase the capacity of cooperative businesses and the expansion of the area being financed, the Sukuk will be issued regularly and constitute a roll-up fund and become a source of funds for the development of religious, health, and other charity activities. To attract more wakif to participate in the Sukuk issuance, it is necessary to have several underwriters who are bookrunner as joint lead underwriter (JLU). Having several JLU in place will provide variety of wakif base both number and distribution. It is also necessary to arrange a public expose to communicate with the potential wakif on the this Sukuk program. Some area need to be emphasized such as the objectives of Sukuk program, size, tenor, coupon, and credit risk of the issuer (Eximbank/ECA) which AAA.

As the fund in place, the financing is ready to be disbursed to the eligible cooperative in the area of red bean and lentils. In time, with the development of red beans and lentils production and exports, these clusters can be developed into red beans and lentils tourism clusters so as to have a wider impact on regional development and equal distribution of regional income. At the maturity date of the Sukuk, the temporary waqf funds will be returned to the wakif which may be reinvested when Eximbank / ECA issues the Sukuk to finance cooperatives for other commodities needed in OIC member countries.

\section{Conclusion}

The results cash waqf in several countries has been used for beneficiaries. Some of them are financing poverty alleviation programs, providing free medical services to the poor and needy, arranging different educational programs and providing entrepreneur development programs. Some of waqf results has been used to finance the burials of poor Muslims, give aid to Muslim orphans, give aid to the schools, and to finance other charity projects.

CWLS, it consists of 2 types, namely wakaf sukuk and retail waqf sukuk. For waqf sukuk, the proceeds of the waqf have been channeled to finance the construction of the retina center and glaucoma center at the hospital. Meanwhile, retail waqf sukuk are used by each nazir to finance the program. This research shows that CWLS is proven to play a role in economic development, particularly infrastructure. The infrastructure that has been built is in the health sector. CWLS can be an alternative source of funds for 
financing commodity exports to OIC member countries. The CWLS end-to-end scheme with underlying trade finance is carried out by prioritizing natural resource optimization that takes into account environmental sustainability, siding with SMEs, economic equality in the regions and competitiveness in the market. As the recommendation, to promote the CWLS there are some action need to be taken. The most important is to conduct socialization regarding CWLS to improve public awareness and enlarge the wakif base.

\section{References}

Ahmad, M. (2015). Role of Waqf in Sustainable Economic Development and Poverty Alleviation: Bangladesh Perspective. Journal of Law, Policy and Globalization, 42, 118-130.

Aziz, M. R. A. (2017). Developing Islamic Waqf Bank as a Mechanism for Financial System Stability. Journal of Islamic Monetary Economics and Finance, 3(1), 61-80.

Azrai, A. A. A. H., Hassan, G. M. A., \& Hanafi, H. (2018). A Proposed Model for Waqf Financing Public Goods and Mixed Public Goods in Malaysia. International Journal of Islamic and Middle Eastern Finance and Management, 11(3), 395-415. https://doi.org/10.1108/IMEFM-01-2017-0001

Çizakça, Murat. (1998). Awqaf in History and Its Implications for Modern Islamic Economies. Islamic Economic Studies, 6(1), 43-70.

Cizakca, M. (2000). A History of Philanthropic Foundations: The Islamic World from the Seventh Century to the Present. Istanbul: Boğaziçi University Press.

Duasa, J., \& Thaker, M. T. (2016). A Cash Waqf Investment Model: an Alternative Model for Financing Micro-enterprises in Malaysia. Journal of Islamic Monetary Economics and Finance, 1(2), 161-188

Greenwood, D. T., \& Holt, R. P. F. (2010). Local Economic Development in the 21st Century. Armonk and London: M. E. Sharpe.

Ismal, R., Muljawan, D., Chalid, M. R., Kashoogie, J., \& Sastrosuwito, S. (2015). Awqaf Linked Sukuk to Support the Economic Developinent. Occasional Paper, 1.

Kahf, M. (1998). Fiqhi Issues in the Revival of Awq $f$. Islamic Horizons.

Kasdi, A. (2016). Peran Nadzir Dalam Pengembangan Wakaf. ZISWAF: Jurnal Zakat dan Wakaf, 1(2), 1-14.

Kasdi, A. (2018). Dinamika Pengelolaan Wakaf dan Potensi Pengembangan Ekonomi di Mesir. ZISWAF: Jurnal Zakat dan Wakaf, 3(2), 14-30.

Mannan, M. A. (1998). Cash Waqf, Enrichment of Family Heritage Generation to Generation. Social Investment Bank Publication Series No. 1.

Masyita, D. (2001). Preliminary Implementation Model Design of Cash Waqf Certificate as Alternative Instrument for Poverty Alleviation in Indonesia using System Dynamics Methodologi. (Unpublished Thesis). Institut Teknologi Bandung.

Masyita, D. (2007). Religious Practices: Waqf: Southeast Asia. Working Paper No. 200704, Department of Management and Business, Padjadjaran University. 
Mohsin, M. I. A. (2013). Financing Through Cash-waqf: a Revitalization to Finance Different Needs. International Journal of Islamic and Middle Eastern Finance and Management, 6(4), 304-321.

Mukhlisin, M., \& Mustafida, R. (2019). Can We Combine Sukuk and Waqf? A Case Study of Indonesia. Revitalization of Waqf for Socio-Economic Development, 1, 169191.

Musari, K. (2019). The Evolution of Waqf and Sukuk toward Sukuk-Waqf in Modern Islamic Economy. International Journal of 'Umranic Studies, 2(1), 45-54.

Nurjamil \& Nurhayati, S. (2021). Sharia Cooperatives' Productive Waqf Management Model Through Financial Technology Services in Bandung City Area to Promote the People's Economy. International Journal of Science, Technology \& Management, 2(1), 272-280. https://doi.org/10.46729/ijstm.v2i1.145

Raissouni, A. (2001). Islamic 'Waqf Endowment': Scope and Implications. Rabat: Islamic Educational, Scientific, and Cultural Organisation (ISESCO).

Saiti, B., Salad, A. J., \& Bulut, M. (2019). The Role of Cash Waqf in Poverty Reduction: A Multi-Country Case Study. Management of Shariah Compliant Businesses, 21-34.

Sanusi, S., \& Shafiai, M. H. M. (2015). The Management of Cash Waqf: Toward SocioEconomic Development of Muslims in Malaysia. Jurnal Pengurusan, 43, 3-12.

Seidman, K. F. (2005). Economic Development Finance. Thousand Oaks: Sage Publications.

Sievers, E. W. (2002). Uzbekistan's Mahalla: from Soviet to Absolutist Residential Community Associations. The Journal of International and Comparative Law at Chicago-Kent, 2(1), 91-158.

Tanjung, H. (2018). An Integration of Waqf and Ventura Capital: A Proposed Model For Indonesia. Journal of Islamic Monetary Economics and Finance, 3, 125 - 140.

Thaker, M. T., Mohammed, M. O., Duasa, J., \& Abdullah, M. A. (2016). Developing Cash Waqf Model as an Alternative Source of Financing for Micro Enterprises in Malaysia. Journal of Islamic Accounting and Business Research, 7(4), 254-267.

Timur, K. (2001). The Provision of Public Goods under Islamic Law: Origins, Impact, and Limitations of the Waqf system. Law and Society Review, 35(4), 841-898.

Todaro, M., \& Smith, S. C. (2011). Economic Development (11th ed.). Pearson Education and Addison-Wesley.

Urif, U. Z., Fajria, M. I. N., \& Rahmi, U. (2019). Zakat and Wakaf (Endowments) Role in Muslims Economic Development of Islamic Economic Perspective. Islamika, 1(2), 133-153.

Zulkhibri, M. (2017). The Nature of Waqf Land and Properties Development in Muslim Countries. In. Zulkhibri, M., \& Ismail, A. (Eds). Financial Inclusion and Poverty Alleviation, Palgrave Studies in Islamic Banking, Finance, and Economics, 271-283. Palgrave Macmillan. 